that is, a little north-west of $\gamma$ Andromedx. The usua characteristic of these meteors is their slow flight, in contrast tc the swift Leonids, and this should facilitate photographic inipressions of them being obtained.

HOL.MES' COMET (1899 d).

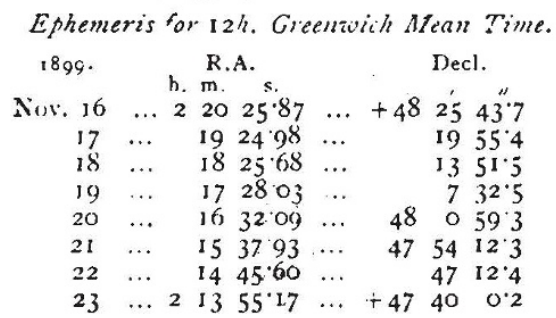

Occultation of Nertuse.-On Sunday evening next November 19, there will be an occultation of Neptune, visible throughout the whole of northern Europe, for the observatior of which the following particulars will be useful :-

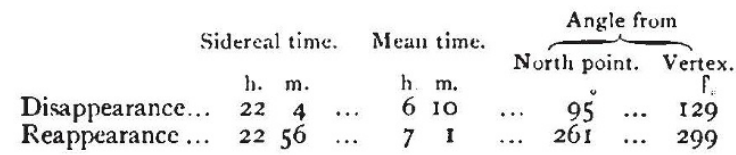

The angles given will facilitate the adjustment of the moon's image so as to bring the points of "immersion" and "emersion" into the positions of best definition. The "angle from the north point" is the angle subtended at the centre of the moon's disc by the arc extending from the star when in contact to the point of intersection of the moon's limb by a great circle passing through the North Pole; the "angie from the vertex" is the angle subtended by the arc extending from the star to the point of intersection of the limb by a vertical great circle passing through the zenith.

For the convenience of observers south of London it may be mentioned that the limits of latitude for this occultation are $90^{\circ} \mathrm{N}$. to $25^{\circ} \mathrm{N}$.

"The Healens at a Giance" (I900).-Mr. Arthur Mee, of Cardiff, has pullished his annual astronomical calendar, upon which is given a concise tabulation of the more important astronomical constants and events for the coming year. One half of the card constitutes a celestial diary, indicating the favourable dispositions of the various constellations for each month. the sun's declination, phases of the moon, and configuration of the planets, with detailed enumeration of occultations and variable star phenomena. Following this, descriptive notes are given of the prominent features visible on the moon at various stages throughout the lunation; times of elongation, opposition, \&c., of the planets throughout the year; a list of the more prominent meteor showers, the eclipses of the year, and several facts concerning variable stars. The whole is printed on a single card, facilitating its being kept within reach for instant reference by the observer's side, and thus specially recommends itself to the amateur who may be unable to spare the time necessary for obtaining the information from the more complete reference works of the observatory. Astronomical time is used throughout, and all the data are for Greenwich, but are applicable with slight corrections to the whole of the British Isles. Not the least important feature is the clear style of arrangement and printing, which will render its use more pleasant under actual working conditions.

\section{THE CONFERENCE OF GERMAN MEN OF SCIENCE AT MUNICHI.}

THE seventy-first meeting of the Society of German Naturalists and Physicians opened at Munich on Sep. tember 17 , and continued until the $23 \mathrm{rd}$.

A great disaster had just visited the city; the floods which had wrought such havoc throughout the Salzkammergut and South Bavaria culminated their work of destruction in Munich, where the Isar, rising many metres in a few hours, destroyed two of the fincst bridges in the capital, inundated the low-lying

$$
\text { NO. I } 568 \text {, VOL. } 61 \text { ] }
$$

parts of the town, and threw out of gear the Flectric Works and niany factories along the banks; many lives were lost.

The Prince Regent bridge, which was entirely destroyed, was the gift of the ruler whose name it bears; the original cost was 1,500,000 marks, and the munificent Prince has undertaken to bear the cost of rebuilding the same.

In spite of the dislocation of all routes of communications, the congress was attended by about 3500 members. The proceedings opened with a gala meeting in the Royal Theatre on Monday, September 18 , when the congress was inaugurated by Councillor von Winckel, and the members were welcomed, on behalf of the Prince Regent, by Prince Lutwig Ferdinand, who evinced his interest by attending all subsequent general mectings.

After several other speeches had been delivered, Dr. Fridtjof Nansen ascended the tribune and summarised the scientific results of his Polar Fxpedition.

Parenthetically, it is interesting to note that three of the most remarkable addresses were delivered by foreigners--Nansen, van t' IHoff and Ramsay-in fluent (;erman.

Nansen strowed the lypical glacial appearance of the Siberian coast, then described Franz Josef's Land, which is far less extensive than appears on the maps; the land is almost entirely covered with ice, relieved here and there with masses of black basalt rocks, which rest on a seam of clay some 500 feet in thickness.

The Arctic Ocean may be considered as a kind of lagoon separated from the Atlantic by a submarine range of mountains, stretching from Spitsbergen to Greenland; this range is responsible for a curious condition of things. The Arctic Ocean is covered with a layer of brackish water containing a low percentage of salt, and collected from the Siberian rivers and the Bering Strait ; below this is Gulf Strean water, containing a normal quantity of salt.

If these two layers of water were mixed, the average temper. ature would fall, but this average would not be so cold as that of the surface layer of Arctic water; this condition accounts for the enormous formation of ice in the polar region.

The points were all illustrated by photographs, tables and diagrams, and drawings of the diatoms found in the fresh-water lakes, formed by the sun melting the surface of the ice, were shown.

The lecturer was followed by Prof. von Bergmann, who demonstrated the value of radiography in the diagnosis of surgicai diseases; and by l'rof. Fïrster, who described the alteration in the face of the heavens from the remotest periods down to the present time.

After these addresses many members adjourned to the Technical College, the whole of which magnificent building had been placed at the disposal of the congress, and where reading and writing rooms, reception and inquiry offices, a restaurant, \&., were to be found.

Here the daily programme was to be obtained, and each member of the congress was presented by the city with an admirable album of views and a "Festschrift."

The Festschrift was a magnificent quarto volume describing the development of Munich under the influence of the natural sciences during the last decades. The first part of the work was devoted to vital statistics and general municipal organisation. A few facts are, however, of general interest and formed the sub. ject of addresses during the congress.

The Electrical Works on the Isar are a most remarkable example of a municipal undertaking; besides the current used for the electric cars, lighting, telegraph and telephone purposes, they supply current to work 172 motors (1 329 H. P.), 13,500 incand. escent and 329 arc-lights in 9I factories. Besides the Corpora. tion works, there are 317 private installations, of which 69 use gas, 39 water, and 179 steam to supply the motive power.

The population of Munich is 450,000 . The cost of lighting the streets (incandescent gas and arc-lights) represented last year, per head of the population, a yearly cost of I.925 marks; in 1881 the cost was less than half this sum, 0.81 mark per head.

()f the two most prominent industries in Munich, the second, the industrial production of cold, originated in the demands ans necessities of the first, the brewing industry.

In 1898 there were 24 breweries, proslucing $1,540,000$ hectolitres of beer. Munich tas always been celcbrated for its beer, and in the year 1500 possessed 38 , in 1618 no less than 69 breweries. 
The industry of the production of low temperatures is due to the energy of, and was initiated by, Dr. Carl Linde, who in I88I, with the help of the Polytechnic Society, started the famous works, where successful experiments were carried out with the "high pressure and low temperature system," and with the happy combination of Siemens' alternating principle with the Joule-Thompson "cooling effect," produced by the streaming of gases from high to low pressures. The following are the chief industrial and scientific uses of low temperatures: manufacture of ice in the brewing industry; preservation of meat and alimentary products generally; preservation of anatomical specimens; in the morgues; the arrestation of the development of the silk cocoon; arrestation of the growth of bulbs (making the same independent of their accustomary flowering season); in the testing of meteorological instruments ; and in scientific research generally ; the preparation of explosives, the fractionation of liquid air, and consequent preparation of mixtures rich in oxygen; the manufacture of ozone.

The Cold Air Storage Installation at Munich is the most complete building of the kind at present erected; the cells are kept constant at $3^{\circ} \mathrm{C}$., and the air contains $60-70$ per cent. of moisture.

The second general meeting was also held in the Royal Theatre, and the addresses on this occasion were delivered by Prof. Boltzmann (Vienna) on the course of the development of modern physical methods; by Prof. Birch-Hirschfeld on science and therapeutics; and by Prof. Klemperer (Berlin) on Justus von Liebig and medical science.

The last-named speaker showed that Liebig initiated the use of chemical preparations of known composition in the place of those plant infusions of doubtful consistency, which formed the staple drugs of the older physicians. Prof. Klemperer declared that the days were drawing near when such extracts would disappear from pharmacology, and chemistry would be entirely substituted for botany.

In another, less direct, way Liebig was the means of enriching our pharmacopœia, for it is by the method of organic analysis he perfected that the composition of the numerous synthetic remedies of to-day is determined. Chloroform and chloral were discovered by him, and, working in a somewhat different region of thought, Liebig exploded the theory that the warmth of the animal organism was in part due to electricity and the action of the nerves, showing that all animal warmth was produced by the chemical processes continually taking place within the organism.

The Chemical Section.

This Section was presided over by Prof. Adolf von Baeyer, Professor of Chemistry at the University of Munich, who welcomed the members of the section, and spoke a few words in memory of Bunsen; the following passage deserves. to be quoted :-

"Bunsen's value as a teacher and master lay not so much in the lectures he delivered as in the example he set. He was always working himself, and worked in the presence of his pupils." 1

Prof. Wislicenus, sen., was elected president for the first day, and won general approval by keeping the speakers strictly to the twenty. minute time limit.

The proceedings were opened by Prof. van t' Hoff (Berlin), who showed that the formation of the Stassfurt salt beds by the evaporation, at $25^{\circ} \mathrm{C}$., of a solution of common salt, borates, and calcium and magnesium sulphate and chloride, could be graphically represented on a diagram.

Richard Meyer gave an account of his experiments on the condensation of aromatic diamines with dibasic acids of the oxalic series!; he showed that in the series :
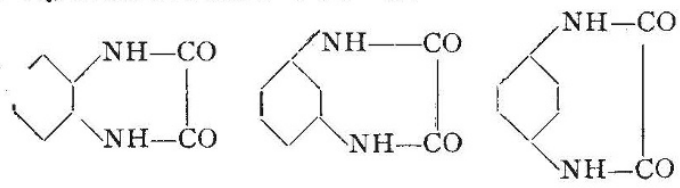

the ortho-derivative alone was stable ; further, that with malonic ether an amino acid ether (I.) was obtained, but with succinic ether a ring (II.)

1 This seems an important pronouncement in view of the disputed ques. tion of the efficacy of private-research rooms as compared with large laboratories.

NO. I 568 , voL. $6 \mathrm{I}]$

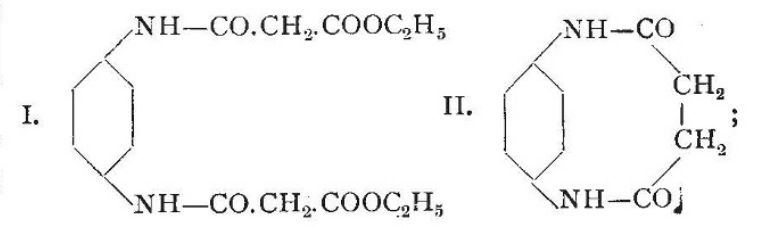

the difference being possibly due to the greater length of the succinic acid chain lessening the tension.

Dr. H. Stobbe (Leipsig) described the condensation products of benzaldehyde with succinic ether, and showed that such a body as dibenzal succinic acid<smiles>O=C(O)C(=Cc1ccccc1)C(=O)O</smiles>

which yields a colourless anhydride is converted by means of iodine into a stereoisomeric acid giving a bright yellow an hydride.

Dr. Krämer (Berlin) advanced certain views as to the formation of petroleum by the decomposition of diatoms; he found that the wax contained in diatomaceous mud consisted largely of decane.

In the subsequent discussion a geologist pertinently remarked that though it was possible that petroleum was formed to a certain extent in this way, yet much larger quantities must be formed by the decomposition of fish and marine animals generally; in confirmation of the animal origin of petroleum he mentioned the fact that many fossil bivalves contained, on opening, drops of oil ; he also suggested that the oil in the Caucasus was formed to some extent by the large number of fish that were killed yearly by passing from the fresh water into the strong brine of the lagoons.

The animal origin of petroleum was acknowledged by all speakers.

I. Tafel followed with a paper on the course of electrolytic reduction. The experiments were carried out with a solution of caffeine, and the rapidity of the reaction measured by the evolution of hydrogen at the kathode as compared with the evolution of hydrogen in a similar cell containing dilute sulphuric acid.

In order to effect reduction Tafel showed that the kathode must be of lead, and, moreover, must be coated by spongy lead, the use of a polished lead pole giving a bad result, immediately rectified by the introduction of a little lead acetate solution. The introduction of copper and the noble metals stopped the reaction, which, in the case of these metals, recovered its normal course ; if platinum had been introduced, there was no recovery. In the discussion Drs. Bodländer, Nernst and Arendt took part, the latter remarking that the anode also should be of lead. Richard Meyer read a second paper on the thio-derivatives of the di- and tri-phenylmethane series, and the influence on the fluorescence of the substitution of sulphur for oxygen in such bodies as<smiles>O=C(O)c1ccccc1</smiles><smiles>c1ccc(Oc2ccccc2)cc1</smiles><smiles>CCCCCCOC(=O)c1ccccc1</smiles>

the results were, however, conflicting.

R. Schenck read a paper on the two kinds of dimorphism and their mutual relationship, describing the course of the change (in the case of para-azoanisole) from enantiomorphism to monotropism.

Dr. Bachhold (Frankfort) gave a short account of the work done by bacteria in the disposal of sewage-in one experiment he took mud from the filter-beds in July and found it to contain I 4.60 per cent. of fats; on preserving this, moist, in a corked flask till November, he found it contained only 5.82 per cent. of fats ; if the mud was previously dried, the percentage, naturally, did not alter.

Prof. Bamberger's (Zürich) address was of especial interest to organic chemists, and was also remarkable in introducing a new expression, which should be welcomed by chemical philologists. He used the expression "torso" to describe the molecular aggregate or residue which had been bereft, so to 
speak, of its limbs; thus represents the torso of diethylaniline, \&c.

In his paper on the mechanism of the passage of hydroxyl. amines into amidophenoles, he described a new class of bodies, quinoles, which only exist at a low temperature, and pass on warming into more stable isomers ; thus he obtained a quinole isomeric with hydroquinone :

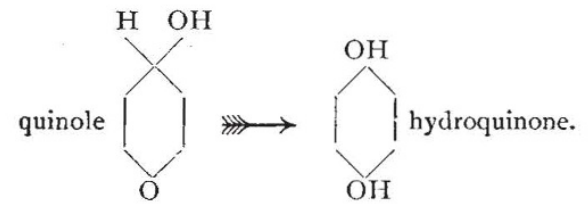

Prof. Lieben (Vienna) gave a general review of the properties and formation of the aldoles, introducing a new classification of these bodies, according to the ease with which they lose waterthe three classes being thus graphically represented :

$\mathrm{CH}_{3}-\mathrm{I}+\mathrm{CH}(\mathrm{OH})-\quad \mathrm{R}_{\mathrm{CH}_{2}} \cdot \stackrel{\mathrm{II}}{\mathrm{CH}}(\mathrm{OH})-\quad \mathrm{R}_{2} \cdot \mathrm{CH}-\stackrel{\mathrm{III}}{-\mathrm{CH}}(\mathrm{OH})-$.

Aldoles belonging to the first class split off water with difficulty, those belonging to the third class with ease.

Prof. Ramsay's address on "The Newly-discovered Gases" was delivered at a combined meeting of the Chemical and Physical Sections, and, despite the early hour at which it was given, attracted a large audience.

As full accounts of these researches have appeared from time to time in NATURE, it will suffice to state that the lecture was illustrated by Crookes' tubes, containing the gases, and to recall the analogy in the periodic system between the group formed by the new gases and the group formed by the halogens

$$
\begin{aligned}
& \mathrm{H}=\mathrm{I} \quad \mathrm{F}=19 \quad \mathrm{Cl}=35^{\circ} 5 \quad \mathrm{Br}=80 \quad \mathrm{I}=127 \\
& \text { Helium }=4 \text { Neon }=20 \text { Argon }=40 \text { Krypton }=82
\end{aligned}
$$

Helium $=4$ Neon $=20$ Argon $=40$ Krypton $=82$ Xenon $=128$

The periodic system, indeed, furnished the subject-matter for several papers in the Chemical Section, and, passing over a paper on this subject, which caused much amusement, it is interesting to note the conclusions arrived at by Prof. Brauner in his investigation of the position of the elements of the rarer earths in this system.

He considers that the position indicated by the fourth group and the eighth series must be assigned to a group of three elements.

Cerium I40, Praseodidymium I40 8 , Neodidymium I $43^{\circ} 6$.

This conclusion is based in great measure on the study of the higher oxides. Prof. Brauner considers that the oxides $\mathrm{Pr}_{2} \mathrm{O}_{4}$ and $\mathrm{Nd}_{2} \mathrm{O}_{4}$ belong to the oxides of the $\mathrm{PbO}_{2}$ or ozonic typethat is to say that the metals in these oxides are tetravalent, and the oxides correspond to $\mathrm{Ce}_{2} \mathrm{O}_{4}$.

At first sight the oxides obtained by precipitation with hydrogen peroxide should belong to the second, $\mathrm{H}_{2} \mathrm{O}_{2}$, or antozonic type of oxide; Prof. Brauner found that on repeating this experiment at low temperatures the hydrates of true superoxides were formed, possessing the formula $\mathrm{Pr}_{2} \mathrm{O}_{5}$ and $\mathrm{Nd}_{2} \mathrm{O}_{5}$, and loosing oxygen with great ease.

Dr. Otto Bleier followed with a paper on "The Vapour Density of Sulphur."

The present methods for the determination of vapour densities cannot be applied with exactitude in experiments performed in order to determine the density of sulphur vapour before the molecules have begun to dissociate.

By a new method, which combines low pressures and low tem peratures, Dr. Bleier showed that, though it was impossible to reach a combination of pressure and temperature at which no dissociation of the sulphur molecule had taken place, yet at $214^{\circ}$ and at a pressure of $4 \mathrm{~m}$. m. the density of the vapour was $7 \cdot 88$, which corresponds to a molecule containing $7 \frac{1}{2}$ atoms; it may therefore be reasonably concluded that the molecule of undissociated sulphur vapour may be represented by $S_{8}$, and not by $\mathrm{S}_{6}$, as given in the text-books.

1 The German expressions Praseodym and Neodym are less cumbersome!

NO. I 568 , vOL. 6I]
Papers were also read by Dr. Staudenmeier on graphitic acid, and by Prof. S. Ruhemann on the acetylene carboxylic acids.

Dr. Nietzki gave the results of investigations undertaken with his pupils on isopurpuric acid, and detailed the grounds on which he assigned to the potassium salt of this acid the formula :<smiles>N#[W]O[Na]</smiles>

Dr. Dulden gave an account of certain researches in the camphor series. Starting with borneol, he obtained amidoborneol, and converted this body by means of phosphorus pentachloride into a substance which, with potash, split off hydrochloric acid to yield camphenamine :

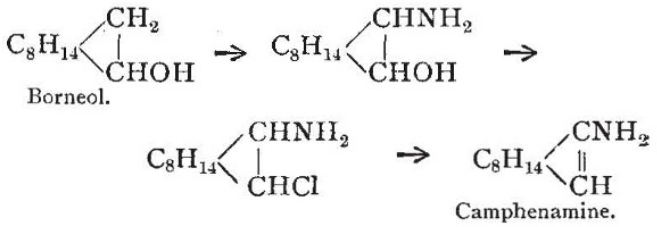

This body shows a considerable analogy with vinylamine, and is a tautomeric compound

$$
\begin{aligned}
& \text { "Enol" form } \quad \ldots \quad \mathrm{C}_{8} \mathrm{H}_{1+} \overbrace{\mathrm{CH}}^{\mathrm{C}-\mathrm{NH}_{2}} \\
& \text { "Ketol" form } \ldots \mathrm{C}_{8} \mathrm{H}_{14} \overbrace{\mathrm{CH}_{2}}^{\mathrm{C}=\mathrm{NH}}
\end{aligned}
$$

The investigator hopes to convert this base into an isomer of camphor by replacing the $\mathrm{NH}_{2}$ group by hydroxyl ; experiments in this direction have led to the isolation of a substance which appears to possess the formula:<smiles>CC(C)(C)C1(C)CCCCC1(C)C</smiles>

Dr. Brauns (Giessen), in a paper on the different modifications of sulphur, described no less than seven distinct varieties. A paper of considerable interest to English chemists described the researches on colloid metals, conducted by Prof. E. von Meyer and Dr. Lattermann, the first example of a metal in this condition having been discovered by Carey Lea.

Mercury, bismuth, copper and silver were obtained in a colloidal condition by reduction of dilute solutions of their salts by means of sub-salts of tin, and subsequent precipitation of the colloid metals by ammonium citrate. Such solutions contained invariably stannic acid in a colloidal condition, and it seems probable that mercury, copper and bismuth can only exist in this state when combined with stannic acid. Colloidal silver when treated with a halogen yields a colloidal solution of the silver halide; true colloids, such as gelatine, increase greatly the stability of the above solutions, which, on the other hand, are immediately precipitated by electrolytes.

The papers in this section were given in the original lecture theatre which Liebig built and which bears his name, and attracted an audience of 100 to 120 daily; at the British Association the morning devoted to organic chemistry did not attract a tenth of this number. The papers began at 9 a.m. and continued, with a pause of fifteen minutes, up to nearly I p.m. ; the section resumed at 3 p.m. and sat again till 5.30 p.m.; two and a half days were occupied by the sessions of this section.

Among the chemists attending the meeting were von Baeyer, van 't Hoff, E. Fischer, Curtius, Kahlbaum, Bernsthen, Ramsay, W. H. Perkin, jun., R. Meyer, H. Stobbe, Bamberger, Brauner (Prague), Hantzsch, Lieben, Einhorn, Ostwald, Werner, J. and W. Wislicenus, Soxhlet, Staudenmeier. 


\section{Other Sections.}

In the Physiological Section Prof. Rudolf Cohn (Königsberg) described a new series of his investigations of the nature of the base obtained by the action of hydrochloric acid on albumen.

He obtained a body possessing the formula $\left(\mathrm{C}_{6} \mathrm{H}_{13} \mathrm{~N}\right)_{2}$, and isomeric with and similar to leucinimide, and probably possess. ing the constitution of dioxydibutyldiethylendiamine. The ease of the formation of such bodies may explain the occurrence of certain bases, such as spermine in the animal organism.

In the Section for Hygiene and Bacteriology an important discussion was inaugurated by Dr. Czaplewski on the method of using formaldehyde (formal, formaline) as a disinfectant.

A remarkable paper was contributed to this section by Dr. Weyl (Berlin) on the sterilisation of water by means of ozone. Water to be sterilised is pumped to the top of a tower and allowed to flow slowly over stones, meeting as it falls a curren of air charged with ozone.

In one experiment with Spree water containing 80,000 90,000 micro organisms per cc., 3000 litres of water were obtained in an hour, containing less than Ioo organisms per cc.

This process appears to be also effectual in purifying peat and bog water, the solution of the iron salts of humic acid being decomposed and oxidised, and the brown colour disappearing in consequence.

The method can be advantageously used in connection with filter-beds, by which the floating organic matter is removed from the water before it is treated with ozonised air.

The cost of sterilising an average river water works out at $\frac{1}{4} d$. to $\frac{1}{2} d$. per 1000 litres; no ozone remains in solution.

In the Physical Section an interesting paper was read by Dr. Carl Linde, on the industrial uses of liquid air.

Prof. Adami's disccurse, in the same section, was remarkable for demonstrating the possibility of constructing dynamos and galvanometers at the cost of a few pence, and the power of performing electrical experiments with the simplest materials. It is impossible in an abstract to give any idea of the charm of Prof. Adami's manipulations.

Prof. C. Kahlbaum's (Basle) experiments on the distillation of metals showed that most metals can be distilled in vacuo, vessels of glass or porcelain being used. Very remarkable is the fact that alloys can be fractionated by this method; in one experiment the copper was quantitatively separated from the nickel in a German coin, the nickel remaining in the flask as a silvery regulus, and the copper crystallising in the receiver; such newly-distilled metals resist to a greater degree the action of atmospheric oxygen.

Prof. Ostwald's paper on periodic changes in the rate of reaction was received with some scepticism, and produced a lively discussion. It appeared that pieces of a certain block of metallic chromium, 5 kilograms in weight, and prepared by Dr. Goldschmidt, showed a remarkable property.

When such pieces were placed in dilute hydrochloric acid, the numbers of the bubbles of hydrogen evolved in equal times, and measured in a capillary tube, exhibited a constant variation; thus in equal periods of time two, four, six and eight bubbles appeared respectively, and then the series recommenced with two bubbles. This truly remarkable phenomenon was confirmed by observations reaching over many months.

Unfortunately, this was the only specimen of metallic chromium which could be obtained possessing this curious property.

All the scientific sections were invited to a meeting in the Kailnstal, where Prof. Chun explained the exhibition of the results of the German Deep Sea Expedition.

These results confirmed in many cases the results obtained on the Challenger expedition, especially as to the existence of life at the greatest depth of the Antarctic Ocean.

When the explorers landed at Kerguelen they were immediately surrounded by great flocks of birds, showing no fear, and perching on the shoulder or pecking at the boots of the astonished members of the expedition.

Some of the fish found at depths of 3000 metres, to which depth naturally but little light penetrates, resembled those found in the Lias, representing a period when the atmosphere of the earth was dense, and charged with carbon; these fish were in some cases provided with special means of collecting light, being in possession of enormous eyes occupying nearly the whole side of the head, or supplied with telescopic organs; in other cases they carried their light with them on their heads, in a somewhat similar fashion to the glow-worm.

NO. I 568 , VOL. 6 I]
On Wednesday afternoon and on Saturday no meetings were held, and a large number of excursions were arranged, comprising visits to the lakes and watering-places near Munich, and excursion to the royal palaces and to Ratisbon.

On Thursday a gala-performance of "Lohengrin" was given at the Opera by royal command, for which every member of the Congress received a ticket.

During the whole week the picture galleries and exhibitions were open to the members at a reduced charge, and opportunities of visiting the breweries, ice-works, \&c., were afforded.

The accommodation of the guests was in the hands of a special committee, who performed their difficult task to the satisfaction of every one, the prices of the rooms being especially moderate.

The next meeting of the Society will be held in September 1900, at Aachen (Aix-la-Chapelle), and, being easy of access, should attract English men of science.

W. T. L.

\section{BOTANY AT THE BRITISH ASSOCIATION}

$T$ HE President of the Section (Sir George King) delivered an address in which he gave a comprehensive sketch of the history of Indian botany. Reports were presented by the committees on assimilation in plants and on fertilisation in the Phæophyceæ. In the former investigations-conducted by Dr. F. F. Blackman (Cambridge)-the experimental work dealt with the sources of the carbon dioxide of leaf assimilation, with the respiration of the stem as distinguished from the leaf, with the magnitude of the absorption of carbon dioxide from the soil, and with kindred problems, of which a preliminary account was given by Dr. Blackman at the Bristol meeting. Mr. Lloyd Williams (Bangor) had been engaged during the past year in researches into the cytology and life-history of various members of the Phæophyceæ, including Dictyota dichotoma, Halidrys szliquosa, Himanthalia lorea, Laminaria saccharina, Alaria esculenta and several species of Fucaceæ.

Mr. Williams contributed a preliminary note on the lifehistory and cytology of Halidrys siliquosa, in which he dealt with the formation and liberation of the sexual cells, the striking phenomena accompanying the act of fertilisation, the segmentation of the spore, together with the cytology of the various processes. In the process of fertilisation the most important points observed were (I) the gyrating, clockwise movement of the antherozoids; (2) the long time taken to effect fertilisation30-50 minutes as against 3-10 minutes in Fucus; (3) the peculiar behaviour of the egg at the moment of fertilisation, its distension and sharp rugged conical projections with beady threads emitted from their apices ; (4) the subsequent restoration of the egg to its normal shape and size.

In accordance with the usual custom, Friday afternoon was - devoted to a semi-popular lecture, which was this year delivered by Mr. Harold Wager, on the sexuality of the fungi. The lecturer gave an interesting and clear account, illustrated by lantern slides, of the phenomena of sexuality in the various groups of fungi.

An additional value was given to the lecture by the number ot new facts dealt with by Mr. Wager; these included some new observations on fertilisation in Peronospora barasitica and Polyphagus Euglenae.

Miss Ethel Sargant gave a demonstration of vermiform nuclei in the fertilised embryo-sac of Lilium Martagon (vide Proc. Roy. Soc., vol. lxv. p. 163, 1899).

Mr. J. C. Willis, Director of the Royal Botanic Garden, Peradeniya, Ceylon, gave an account of the research laboratory and of the facilities afforded to botanists conducting investigations in the Ceylon Gardens.

On Saturday, September I6, Mr. G. Dowker, the local secretary of Section $\mathrm{K}$, whose intimate knowledge of the Kent flora made him an admirable leader, conducted a botanical excursion to Sandwich. Those who were present at the meetings of Section $\mathrm{K}$ will learn with sincere regret that $\mathrm{Mr}$. Dowker died suddenly on Friday, September 22. The botanists present at Dover had learned in their short acquaintance with Mr. Dowker to appreciate his kindly nature and the keen interest he took in botanical work.

Thallophyta.

Prof. Marshall Ward gave an account of his recent work on Onygena equina, a horn-destroying fungus (Proc. Roy. Soc. 